\title{
PENGEMBANGAN INSTRUMEN PENILAIAN PENGETAHUAN AWAL (PRIOR KNOWLEDGE) MAHASISWA PADA MATERI TERMOKIMIA
}

\author{
Riva Ismawati ${ }^{1}$, Eli Trisnowati ${ }^{2}$
}

${ }^{1,2}$ Prodi Pendidikan IPA, Universitas Tidar, Jalan Kapten Suparman no. 39 Magelang

\begin{abstract}
This study aims to determine the characteristics of testlet assessment instrument items of student's prior knowledge on thermo chemistry material. The method used in this research was research and development method of 3-D model (Define, Design, and Develop). Instruments were piloted on 39 students and validated by experts. Instrument reliability (r11) of the instrument was 0.9 with very high category. The validity of the items consisted of 42 valid questions, and 3 invalid questions. The difficulty index of item consisted of 7 difficult questions, 34 moderate questions, and 4 easy questions. Discrimination index of item consisted of 7 questions bad category, 17 questions enough category, 20 questions good category, and 1 question very good category.

Keywords: assessment instrument, prior knowledge, teslet, thermochemistry
\end{abstract}

\begin{abstract}
Abstrak
Penelitian ini bertujuan untuk menentukan karakteristik butir soal instrumen penilaian pengetahuan awal (prior knowledge) mahasiswa berbentuk tes teslet pada materi termokimia. Metode yang digunakan dalam penelitian ini adalah metode penelitian dan pengembangan model 3-D (Define, Design, Develop). Instrumen divalidasi oleh ahli dan diujicobakan pada 39 mahasiswa. Reliabilitas instrumen $r_{11}$ sebesar 0,9 dengan kategori sangat tinggi. Validitas butir soal terdiri dari 42 soal valid, dan 3 soal tidak valid. Tingkat kesulitan butir soal terdiri dari 7 soal sukar, 34 soal sedang, dan 4 soal mudah. Daya pembeda butir soal terdiri dari 7 soal jelek, 17 soal cukup, 20 soal baik, dan 1 soal sangat baik.
\end{abstract}

Kata kunci: instrumen penilaian, pengetahuan awal, testlet, termokimia.

\section{PENDAHULUAN}

Kimia sebagai bagian dari sains mempelajari fenomena alam berdasarkan kegiatan eksperimen. Terdapat empat dimensi sains yaitu sains sebagai cara berfikir, penyelidikan, kumpulan pengetahuan, serta interaksi sains dengan teknologi dan masyarakat (Chiapetta \& Koballa, 2010). Oleh karena itu, pembelajaran sains yang berkualitas diharapkan dapat memecahkan berbagai masalah yang ditimbulkan oleh kemajuan IPTEK. Sayangnya, masih ditemukan peserta didik yang mengalami kesulitan 
dalam mempelajari materi kimia seperti termokimia.

Kesulitan yang dialami peserta didik dalam mempelajari konsep termokimia diantaranya (1) membedakan kalor dengan suhu, (2) prinsip kalorimeter dan pertukaran energi pada reaksi dalam kalorimeter, (3) mengidentifikasi reaksi eksoterm dan endoterm (Yalcinkaya et al., 2009). Pemahaman peserta didik terhadap konsep termodinamika juga masih rendah, diantaranya (1) hubungan antara energi, entalpi, dan ikatan dalam reaksi kimia, (2) perubahan panas, suhu, dan entalpi dalam perubahan fasa, (3) hubungan antara panas, suhu, masa dan kalor jenis (Saricayir et al., 2016).

Kesulitan belajar tidak hanya disebabkan oleh kurangnya kemampuan kognitif, namun juga disebabkan peserta didik tidak memiliki pengetahuan awal (prior knowledge) yang dibutuhkan untuk mempelajari pengetahuan baru (Howe dalam Westwood, 2004). Sementara itu, Mosik \& Maulana (2010) menyatakan bahwa peserta didik yang datang ke kelas sudah memiliki pengalaman dan pengetahuan sebelumnya yang berkaitan dengan pelajaran yang akan dipelajari.

Pengetahuan awal merupakan kumpulan pengetahuan serta pengalaman seseorang yang didapatkan selama hidup dan akan digunakan dalam pengalaman belajar yang baru (Arends, 1997). Pengetahuan awal yang dimiliki peserta didik memainkan peranan penting dalam kegiatan pembelajaran diantaranya dalam pembentukan pengetahuan baru serta merangsang kemampuan pemecahan masalah peserta didik (Halilikari, 2009; Zakaria \& Yussof, 2009; Suastra, 2009; Suyanto, 2010). Oleh sebab itu, pendidik perlu mengetahui pengetahuan awal mahasiswa sebelum kegiatan pembelajaran.

Mahasiswa Prodi Pendidikan IPA telah mempelajari materi termokimia pada pelajaran kimia di bangku SMA. Di perguruan tinggi, materi termokimia akan dipelajari kembali pada mata kuliah kimia dasar. Pengetahuan awal mahasiswa mengenai konsep termokimia dapat diketahui dengan melakukan tes diagnosis. Tes uraian diketahui sebagai alat diagnosis yang mampu memberikan informasi mengenai kemampuan penempuh tes. Namun, Pemeriksaan hasil pekerjaan tes uraian membutuhkan waktu yang lama. Selain itu, relatif sulit untuk memeriksa dan memberikan penilaian pada hasil pekerjaan tes uraian. Tes diagnosis lainnya adalah pilihan ganda. Tes pilihan ganda lebih efisien dalam pemeriksanaan hasil pekerjaan dan penilaian. Akan tetapi, tes pilihan ganda kurang mampu memberi informasi penempuh tes (Susongko, 2010).

Instrumen yang memadukan kelebihan tes pilihan ganda dan tes uraian yaitu test 
bentuk testlet. Testlet merupakan sekumpulan butir soal yang mengungkap informasi yang sama dimana butir soal tersebut dianggap dan diperlakukan sebagai satu kesatuan soal (Embretson \& Reise, 2000). Jawaban benar pada setiap soal dapat menyampaikan secara keseluruhan, sebagian, ataupun tidak sama sekali informasi kepada peserta didik sebelum melanjutkan soal berikutnya dengan pengetahuan penuh untuk jawaban yang benar (Shiell \& Slepkov, 2015).

Berdasarkan uraian diatas perlu dikembangkan instrumen tes yang dapat mendiskripsikan pengetahuan awal mahasiswa terhadap konsep termokimia. Oleh karena itu, peneliti bertujuan untuk mengembangkan instrumen tes bentuk testlet pengetahuan awal (prior knowledge) mahasiswa pada materi termokimia dengan menentukan karakteristik butir soal instrumen.

\section{METODE PENELITIAN}

Penelitian dilaksanakan pada bulan Maret 2018 di Prodi Pendidikan IPA Universitas Tidar. Populasi dalam penelitian ini adalah mahasiswa S1 Prodi Pendidikan IPA Universitas Tidar semester 2. Pengambilan sampel pada penelitian ini menggunakan teknik cluster random sampling. Sampel penelitian adalah mahasiswa S1 Prodi Pendidikan IPA Universitas Tidar semester 2 kelas 1 sebanyak 39 mahasiswa.

Penelitian ini merupakan penelitian dan pengembangan model 3-D (Define, Design, Develop) (Thiagarajan, 1974). Tahapan dalam penelitian ini meliputi pendefinisian (define), desain (design), dan pengembangan (develop).

\section{Pendefinisian (define)}

Tahap pendefinisian dilakukan analisis front-end, analisis kebutuhan, analisis tugas, analisis mahasiswa, dan analisis konsep. Permasalahan yang dihadapi dalam kegiatan pembelajaran termokimia adalah peserta didik mengalami kesulitan mempelajari konsep termokimia dan pemahaman konseptual termokimia yang rendah. Mahasiswa pernah belajar mengenai termokimia pada saat mahasiswa duduk di bangku SMA. Pengetahuan termokimia yang diperolehnya menjadi bekal untuk mempelajari konsep yang sama atau yang lebih luas pada jenjang perguruan tinggi. Faktanya belum ada instrumen yang digunakan untuk mengukur pengetahuan awal mahasiswa pada konsep termokimia.

Berdasarkan kesenjangan pada tahap analisis front-end maka diperlukan 
penyusunan instrumen penilaian berdasarkan pengetahuan awal mahasiswa pada konsep termokimia. Oleh karena itu, diperlukan instrumen untuk mengukur pengetahuan awal mahasiswa, mengingat bahwa mahasiswa Prodi Pendidikan IPA berasal dari berbagai SMA maupun SMK baik negeri maupun swasta. Analisis konsep bertujuan untuk mengidentifikasi konsep-konsep pada materi termokimia yang meliputi hukum kekekalan energi, jenis entalpi molar, penentuan entalpi reaksi, serta bahan bakar.

\section{Desain (Design)}

Tahap desain bertujuan untuk menghasilkan rancangan instrumen tes pengetahuan awal mahasiswa pada konsep termokimia. Instrumen tes yang digunakan dalam penelitian ini adalah bentuk testlet.

\section{Pengembangan (Develop)}

Pada tahap pengembangan dilakukan uji validitas terhadap instrument tes. Uji validitas meliputi validitas konstruk dan validitas isi. Uji validitas konstruk oleh pakar. Pada uji validitas konstruk dilakukan pengujian pada format instrumen, isi instrumen, konstruksi instrumen dan bahasa yang digunakan. Hasil uji validitas konstruk dievaluasi dan digunakan untuk memperbaiki instrumen. Instrumen yang telah diperbaiki kemudian dilakukan uji validitas isi. Hasil uji validitas isi kemudian dievaluasi dan digunakan untuk memperoleh instrumen yang dapat digunakan untuk penelitian selanjutnya.

\section{HASIL DAN PEMBAHASAN}

\section{Rancangan Produk Awal}

Instrumen penilaian pengetahuan awal mahasiswa pada konsep termokimia telah disusun berupa tes bentuk teslet pilihan ganda berjumlah 45 butir soal yang terdiri dari 15 soal utama dan 3 soal pendukung. Instrumen dikembangkan berdasarkan standar kompetensi dan indikator.

\section{Validasi Konstruk oleh Pakar/Ahli}

Sebelum dilakukan uji coba, instrumen penilaian pengetahuan awal mahasiswa ditelaah terlebih dahulu oleh pakar. Telaah yang dilakukan meliputi telaah kuantitatif dan kualitatif. Telaah kuantitatif oleh pakar menggunakan angket dengan skala linkert rentang 1-4 yang meliputi 4 aspek penilaian yaitu format instrumen, isi instrumen, konstruksi, dan bahasa. Rangkungan hasil telaah kuantitatif instrumen 
disajikan pada Tabel 1.

Tabel 1. Hasil Telaah Kuantitatif Instrumen

\begin{tabular}{clcc}
\hline No & \multicolumn{1}{c}{ Aspek } & Pakar I & Pakar II \\
\hline 1 & Format instrument & 4 & 3,8 \\
2 & Isi instrument & 3,7 & 3,3 \\
3 & Konstruksi & 3,7 & 3,6 \\
4 & Bahasa & 3,7 & 3,7 \\
Rata-rata & & 3,8 & 3,6 \\
Kriteria & & Sangat Valid & Sangat Valid \\
\hline
\end{tabular}

Berdasarkan Tabel 1 dapat diketahui bahwa rata-rata penilaian pakar I dan pakar II terhadap instrumen berturut-turut sebesar 3,8 dan 3,6 termasuk kriteria sangat valid. Hasil telaah kualitatif berdasarkan komentar dan saran perbaikan dari pakar. Diantaranya adalah penambahan data Ar unsur pada soal, perbaikan penulisan satuan, masih terdapat pilihan jawaban angka yang belum diurutkan dari besar ke kecil atau sebaliknya, penambahan keterangan sumbu $\mathrm{x}$ dan $\mathrm{y}$ pada grafik, penambahan kata adalah diakhir soal. Berdasarkan komentar dan saran perbaikan tersebut maka dilakukan perbaikan pada instrumen.

\section{Hasil Uji Coba}

Uji coba instrumen dilakukan untuk mendapatkan data validitas, reliabilitas, tingkat kesukaran, dan daya beda butir soal.

a. Validitas

Instrumen yang valid merupakan instrumen yang dapat digunakan untuk mengukur keadaan yang sesungguhnya pada obyek yang diteliti (Sugiyono, 2008). Hasil analisis validitas terhadap 45 butir soal pilihan ganda dengan 15 soal utama dan 3 soal pedukung disajikan pada Tabel 2.

Tabel 2. Hasil analisis validitas butir soal

\begin{tabular}{llc}
\hline \multicolumn{1}{c}{ Kriteria } & \multicolumn{1}{c}{ Nomor soal } & Jumlah \\
\hline Valid & $1,2,3,4,5,6,7,8,9,10,11,12,13,14,15$, & 42 \\
& $16,17,18,19,20,22,23,24,25,26,27,28$, & \\
& $29,30,31,32,33,34,35,36,37,40,41,42$, & \\
& 43,44, dan 45. & 3 \\
Tidak valid & 21,38, dan 39. & \\
\hline
\end{tabular}


Hasil analisis validitas butir soal diketahui sebanyak 42 soal valid dan 3 soal tidak valid. Hanya butir soal yang valid yang digunakan dalam penelitian selanjutnya. Instrumen yang digunakan dalam penelitian ini adalah tes bentuk teslet yaitu setiap 1 soal utama terdiri atas 3 soal pendukung. Oleh karena itu, jika terdapat soal yang tidak valid maka soal pendukung terkait tidak digunakan. Misal soal no 21 terkait dengan soal no 19 dan 20. Karena no 21 tidak valid maka soal no 19 dan 20 tidak digunakan.

b. Reliabilitas

Instrumen yang reliabel merupakan instrumen yang digunakan beberapa kali untuk mengukur obyek yang sama akan menghasilkan data yang sama (Sugiyono, 2008). Reliabilitas soal dihitung mengunakan rumus Kuder Richardson, yaitu KR21. Berdasarkan hasil analisis reliabilitas menggunakan KR-21 didapatkan harga $\mathrm{r}_{11}$ sebesar 0,90 dengan kriteria sangat tinggi.

Intepretasi terhadap nilai koefisien reliabilitas bersifat relatif. Hal tersebut memberikan arti bahwa tidak ada batasan mutlak yang menunjukkan berapa angka koefisien minimal yang harus dicapai agar suatu pengukuran bersifat reliabel. Koefisien reliabilitas hanya memberikan informasi tentang hubungan varians skor teramati dengan dengan varian skor sejati kelompok individu (Matondang, 2009). Oleh karena itu, koefisien relatif penelitian $r_{11}$ sama dengan 0,90 dapat diartikan bahwa (a) $90 \%$ varians skor teramati diakibatkan oleh varians sejati kelompok individu; dan (b) korelasi antara sekor teramati dan skor sejati sama dengan $\sqrt{0,9}$ atau sama dengan 0,95 .

c. Tingkat Kesukaran

Soal yang baik adalah soal yang tidak terlalu mudah maupun tidak terlalu sukar. Soal yang terlalu mudah tidak dapat merangsang peserta didik berusaha menyelesaikannnya. Soal yang terlalu sukar akan menyebabkan peserta didik putus asa dan tidak mempunyai semangat untuk menyelesaikan soal karena diluar kemampuannya (Arikunto, 2009). Tingkat kesukaran butir soal ditunjukkan oleh suatu bilangan yang disebut indeks kesukaran. Hasil analisis tingkat kesukaran soal dalam penelitian ini disajikan dalam Tabel 3. 
Tabel 3. Hasil Analisis Tingkat Kesukaran Soal

\begin{tabular}{|c|c|c|c|}
\hline Kriteria & Interval & Nomor soal & Jumlah \\
\hline Sukar & $0,00<P \leq 0,30$ & $23,24,29,30,36,38$, dan 39 & 7 soal \\
\hline Sedang & $0,30<P \leq 0,70$ & $\begin{array}{l}2,4,5,6,7,8,9,10,11,12,13, \\
14,15,16,18,19,20,21,22,25, \\
26,27,28,31,32,33,34,37,40, \\
41,42,43,44, \text { dan } 45 .\end{array}$ & 34 soal \\
\hline Mudah & $0,70<P \leq 1,00$ & $1,3,17$, dan 35 . & 4 soal \\
\hline
\end{tabular}

Indeks kesukaran diberi simbol $P$ yang merupakan singkatan dari proporsi. Dengan demikian, butir soal dengan $P=0,6$ lebih mudah dibandingkan dengan butir soal dengan $P=0,2$. Hasil analisis tingkat kesukaran butir soal diketahui sebanyak 7 soal dengan tingkat kesukaran sukar, 34 soal dengan tingkat kesukaran sedang, dan 4 soal dengan kriteria mudah.

d. Daya Beda

Analisa daya beda soal digunakan untuk mengetahui kemampuan suatu soal dalam membedakan antara peserta didik berkemampuan tinggi dengan peserta didik berkemampuan rendah (Arikunto, 2009). Daya beda suatu soal ditunjukkan oleh suatu bilangan yang disebut indeks diskriminasi $(D)$. Hasil analisis tingkat kesukaran soal disajikan dalam Tabel 4.

Tabel 4. Hasil Analisis Daya Pembeda Soal

\begin{tabular}{lcll}
\hline \multicolumn{1}{c}{ Kriteria } & \multicolumn{1}{c}{ Interval } & \multicolumn{1}{c}{ Nomor soal } & Jumlah \\
\hline Jelek & $0,00<D \leq 0,20$ & $20,21,34,35,37,38$, dan 39 & 7 soal \\
Cukup & $0,20<D \leq 0,40$ & $1,3,7,10,11,15,17,23,24,25$, & 17 soal \\
& & $26,27,28,30,36,41$, dan 43 & \\
Baik & $0,40<D \leq 0,70$ & $2,4,5,6,9,12,13,14,16,18,19$, & 20 soal \\
& & $22,29,31,32,33,40,42,44$, dan & \\
& & 45 & 1 soal \\
\hline
\end{tabular}

Hasil analisis tingkat kesukaran butir soal diketahui 7 soal dengan kriteria jelek, 17 soal dengan kriteria cukup, 20 soal dengan kriteria baik, dan 1 soal 
dengan kriteria sangat baik.

\section{Kajian Produk Akhir}

Instrumen yang dikembangkan dalam penelitian ini berupa tes bentuk testlet yang digunakan untuk mengetahui tingkat pengetahuan awal mahasiswa pada materi konsep termokimia. Berdasarkan uji validasi pakar/ahli dan uji coba yang dilaksanakan, produk akhir penelitian adalah soal yang memenuhi kriteria valid, reliabel, daya pembeda minimal cukup dan soal yang tidak terlalu sukar atau terlalu mudah. Produk akhir sebanyak 33 soal dengan 11 soal utama dan 3 soal pendukung seperti yang disajikan dalam Tabel 4.

Tabel 4. Hasil Produk Akhir

\begin{tabular}{lll}
\hline \multicolumn{1}{c}{ Kriteria } & \multicolumn{1}{c}{ Nomor soal } & Jumlah \\
\hline Soal layak & $1,2,3,4,5,6,7,8,9,10,11,12,13,14,15$, & 41 soal \\
pakai & $16,17,18,19,21,22,23,24,25,26,27,28$, & \\
& $29,30,31,32,33,34,35,36,40,41,42,43$, & \\
& 44, dan 45. & \\
Soal dipakai & $1,2,3,4,5,6,7,8,9,10,11,12,13,14,15$, & 33 soal \\
& $16,17,18,22,23,24,28,29,30,31,32,33$, & \\
& $40,41,42,43,44$, dan 45. & \\
\hline
\end{tabular}

Soal pendukung tes teslet dapat bersifat dependent atau independent. Soal pendukung tes teslet yang dikembangkan dalam penelitian ini bersifat dependent. Soal pendukung dependent berarti soal pendukung pertama memberikan informasi dan menjadi dasar untuk menyelesaikan soal dependent berikutnya. Dengan demikian, jika penempuh tes menjawab salah soal pendukung nomor 1 , maka siswa tidak dapat menjawab benar soal pendukung berikutnya (Yamtinah et al., 2014). Oleh karena itu, produk akhir penelitian harus memperhatikan validitas, tingkat kesukaran, dan daya beda soal pendukung terkait. Contoh produk akhir dapat dilihat pada Tabel 5.

Tabel 5. Produk Akhir Pengembangan Soal Pilihan Ganda Bentuk Testlet

\section{Pernyataan berikut untuk soal no 16, 17, dan 18 :}

Semakin menipisnya cadangan bahan bakar fosil menjadikan manusia berupaya untuk mencari bahan bakar alternatif. Salah satunya adalah bioetanol. Bioetanol adalah etanol yang dihasilkan dari fermentasi glukosa (gula) yang dilanjutkan 
dengan proses distilasi. Pembakaran etanol lebih bersih daripada bahan bakar fosil yang berarti mengurangi emisi gas rumah kaca. Hal ini merupakan keuntungan etanol yang paling signifikan bagi lingkungan dibandingkan dengan bahan bakar fosil. Pembakaran sempurna dari 4,6 gram etanol $\mathrm{C}_{2} \mathrm{H}_{5} \mathrm{OH}$ dibebaskan energi sebesar $27,77 \mathrm{~kJ}$.

16. Persamaan reaksi pembakaran sempurna gas etanol yang telah setara adalah....
a. $\mathrm{C}_{2} \mathrm{H}_{5} \mathrm{OH}_{(\mathrm{g})}+\mathrm{O}_{2(\mathrm{~g})} \longrightarrow \mathrm{CO}_{2(\mathrm{~g})}+\mathrm{H}_{2} \mathrm{O}_{(\mathrm{g})}$
b. $\mathrm{C}_{2} \mathrm{H}_{5} \mathrm{OH}_{(\mathrm{g})}+3 \mathrm{O}_{2(\mathrm{~g})} \longrightarrow 2 \mathrm{CO}_{2(\mathrm{~g})}+3 \mathrm{H}_{2} \mathrm{O}_{(\mathrm{g})}$
c. $\mathrm{C}_{2} \mathrm{H}_{5} \mathrm{OH}_{(\mathrm{g})}+\mathrm{O}_{2(\mathrm{~g})} \longrightarrow \mathrm{CO}_{(\mathrm{g})}+\mathrm{H}_{2} \mathrm{O}_{(\mathrm{g})}$
d. $\mathrm{C}_{2} \mathrm{H}_{5} \mathrm{OH}_{(\mathrm{g})}+2 \mathrm{O}_{2(\mathrm{~g})} \longrightarrow 2 \mathrm{CO}_{(\mathrm{g})}+3 \mathrm{H}_{2} \mathrm{O}_{(\mathrm{g})}$
e. $\mathrm{C}_{2} \mathrm{H}_{5} \mathrm{OH}_{(\mathrm{g})} \longrightarrow 2 \mathrm{C}_{(\mathrm{s})}+3 \mathrm{H}_{2(\mathrm{~g})}+1 / 2 \mathrm{O}_{2(\mathrm{~g})}$

17. Entalpi pembakaran sempurna 1 mol gas $\mathrm{C}_{2} \mathrm{H}_{5} \mathrm{OH}$ adalah....
a. $+277,7 \mathrm{~kJ}$
b. $+138,85 \mathrm{~kJ}$
c. $-277,7 \mathrm{~kJ}$
d. $-138,85 \mathrm{~kJ}$
e. $416,55 \mathrm{~kJ}$

18. Jumlah mol oksigen yang diperlukan agar dibebaskan kalor 555,4 kJ adalah....
a. $4 \mathrm{~mol}$
b. $6 \mathrm{~mol}$
c. $8 \mathrm{~mol}$
d. $10 \mathrm{~mol}$
e. $12 \mathrm{~mol}$

Berdasarkan Tabel 5, mahasiswa dapat menyelesaikan soal nomor 18 jika mahasiswa mampu menjawab benar soal nomor 16 dan 17. Oleh karena itu, informasi yang diperoleh pada soal nomor 16 dan 17 menjadi dasar untuk menjawab soal nomor 18. Jika soal nomor 16 salah maka nomor 17 dan 18 dianggap salah. Berdasarkan penskoran tersebut dosen dapat menentukan pengetahuan awal mahasiswa mengenai konsep termokimia yang telah mereka peroleh dari bangku SMA/SMK dan dapat merencanakan kegiatan pembelajaran yang tepat. 
Pengembangan tes teslet juga telah dilakukan sebelumnya. Wahyuni et al. (2015) dan Kusumaningrum et al. (2015) telah mengembangkan intrumen pendeteksi kesulitan belajar kimia model testlet dengan soal pendukung dependent. Sementara itu, Slepkov (2013) dan Slepkov \& Shiell (2014) telah mengembangkan integrated teslet dimana soal pendukung dalam test teslet bersifat dependent dan independent.

\section{SIMPULAN}

Rata-rata penilaian validasi pakar I dan pakar II terhadap instrumen termasuk kriteria sangat valid. Tidak ada saran perbaikan yang mendasar dari pakar terhadap instrumen. Reliabilitas instrumen $\mathrm{r}_{11}$ diperoleh 0,9 dengan kategori sangat tinggi. Validitas butir soal terdiri dari 42 soal valid, dan 3 soal tidak valid. Tingkat kesulitan butir soal terdiri dari 7 soal sukar, 34 soal sedang, dan 4 soal mudah. Daya pembeda butir soal terdiri dari 7 soal jelek, 17 soal cukup, 20 soal baik, dan 1 soal sangat baik. Produk akhir instrumen yaitu 33 butir soal dengan 11 soal utama dan 3 soal pendukung. 


\section{DAFTAR PUSTAKA}

Arends, R. (1997). Classroom instruction and management. McGraw-Hill Companies.

Arikunto, S. (2009). Dasar-dasar evaluasi pendidikan. Jakarta: Bumi Aksara.

Chiappetta, E.L., \& Koballa, T.R. (2010). Science Instruction in The Middle and secondary School $7^{\text {th }}$ Edition. Boston: Allyn \& Bacon.

Embretson, S., E., \& Reise, S., P. (2000). Item Respon Theory for Psychologists. Mahwah, N. J.: Lawrence Erlbaum Associates.

Hailikari, T. (2010). Assessing university students' prior knowledge.

Kusumaningrum, L., Yamtinah, S., \& Saputro, A. N. C. (2015). Pengembangan instrumen tes diagnostik kesulitan belajar kimia SMA kelas XI semester I menggunakan model teslet. Jurnal Pendidikan Kimia, 4(4), 36-45.

Matondang, Z. (2009). Validitas dan reliabilitas suatu instrumen penelitian. Jurnal Tabularasa, 6(1), 87-97.

Maulana, P. (2010). Usaha Mengurangi Terjadinya Miskonsepsi Fisika Melalui Pembelajaran dengan Pendekatan Konflik Kognitif. Jurnal Pendidikan Fisika Indonesia, 6(2).

Saricayir, H., Ay, S., Comek, A., Cansiz, G., \& Uce, M. (2016). Determining Students' Conceptual Understanding Level of Thermodynamics. Journal of Education and Training Studies, 4(6), 69-79.

Shiell, R., \& Slepkov, A. (2015). Integrated Testlets: A New Form of Expert-Student Collaborative Testing. Collected Essays on Learning and Teaching, 8, 201-210.

Slepkov, A. D. (2013). Integrated testlets and the immediate feedback assessment technique. American Journal of Physics, 81(10), 782-791.

Slepkov, A. D., \& Shiell, R. C. (2014). Comparison of integrated testlet and constructed-response question formats. Physical Review Special Topics-Physics Education Research, 10(2), 020120.

Suastra, I. W. (2009). Pembelajaran sains terkini: Mendekatkan siswa dengan lingkungan alamiah dan sosial budayanya. Singaraja: Universitas Pendidikan Ganesha.

Sugiyono. (2008). Metode penelitian pendidikan:(pendekatan kuantitatif, kualitatif dan $R \& D)$. Alfabeta.

Susongko, P. (2010). Perbandingan keefektifan bentuk tes uraian dan testlet dengan penerapan graded response model (GRM). Jurnal Penelitian dan Evaluasi 
Pendidikan, 14(2), 269-288.

Suyanto, K., E. (2010). Model-Model pembelajaran. Malang: Kementrian Pendidikan nasional Universitas Negeri Malang Panitia Sertifikasi Guru (PSG) Rayon 15.

Thiagarajan, S. (1974). Instructional development for training teachers of exceptional children: A sourcebook.

Wahyuni, I. T., Yamtinah, S., \& Utami, B. (2015). Pengembangan Instrumen Pendeteksi Kesulitan Belajar Kimia Kelas X Menggunakan Model Testlet. Jurnal Pendidikan Kimia, 4(4), 222-231.

Westwood, P. S. (2004). Learning and learning difficulties: A handbook for teachers. Aust Council for Ed Research.

Yalcinkaya, E., Tastan, O., \& Boz, Y. (2009). High School Students' Conceptions about Energy in Chemical Reactions. Journal of Pamukkale University Education Faculty. 26: 1-11.

Yamtinah, S. Haryono, \& Martini, KS 2014. Profil Individu Peserta Didik Pelengkap Tes Jenis Testlet sebagai Alternatif Pendeteksi Kesulitan Belajar Kimia. Jurnal Profesi Pendidikan, 1(01), 1-10.

Zakaria, E., \& Yusoff, N. (2009). Attitudes and problem-solving skills in algebra among Malaysian matriculation college students. European Journal of Social Sciences, $8(2), 232-245$. 